\title{
Gender Inequity and Academic Progression: How Much of Our Silence Is Chosen?
}

\author{
Pooja Sawrikar (D)
}

Citation: Sawrikar, P. Gender Inequity and Academic Progression: How Much of Our Silence Is Chosen? Societies 2021, 11, 23. https://doi.org/10.3390/soc11010023

Received: 12 March 2021

Accepted: 12 March 2021

Published: 16 March 2021

Publisher's Note: MDPI stays neutral with regard to jurisdictional claims in published maps and institutional affiliations.

Copyright: (c) 2021 by the author Licensee MDPI, Basel, Switzerland. This article is an open access article distributed under the terms and conditions of the Creative Commons Attribution (CC BY) license (https:// creativecommons.org/licenses/by/ $4.0 /)$.
Independent Researcher, Gold Coast 4223, Australia; p.sawrikar@promotingwomeninacademia.com

In late 2019, I was invited by Societies Journal to establish a Special Issue on a topic of my choosing. This alone is a fact worth noting and celebrating. According to Holman, Stuart-Fox, and Hauser, men in STEM (Science, Technology, Engineering, and Mathematics) are twice as likely to be invited to submit journal articles [1]. I am not sure what the ratio is in the social sciences, nor for editorials as opposed to empirical work, but that someone might think my voice was worth carving space out for in the world, and that with that platform a light could be shed on a serious issue a woman of color thinks is worth considering, I would have good grounds to suspect is not the norm.

I chose the issue of gender inequity and academic progression because it was pertinent to my experiences at the time. I was applying for promotion to Level D (Associate Professor), which only those who knew me knew was long overdue. It was my years in the business and the intel accrued over those decades that people around me valued. I intended on finally addressing the gap between what I knew and what I was being paid for what I knew in 2020. The pandemic then hit, universities delayed or froze their promotions round, and everyone took deep stock of their life.

For ten years prior, I was bogged in the physically unrelenting and structurally unsupported social duty of motherhood expected of me. At the beginning of that journey, my head was full of thoughts like "but I chose this, so it's my responsibility". With the power of that personal agency fueling my daily activities, I moved mountains. I achieved less objectively than the person not bogged, but everything I did was still completed on time- - thorough and polished. Each day, I would conquer Mount Everest to see my jobs through, so I had nothing but pride in the work I had made (even on the days I said I didn't). It took a long life-cycle to play out and work out that I had been trained by a history eons-old to see wanting a family as personal choice, not a human instinct to belong, shared by all the members that created it.

The rhetoric of choice both gave and took power-a slippery self-serving game played by the workplace. It allowed them to take the labor I was offering at the cheapest legal price, and simultaneously fail to see what I was doing, care for the contribution I was making, thank me, pay me, make me feel good, and ... just be nice. I climbed that mountain every day by flogging myself seven days a week, night and day, for ten years, only to be met with the words to my 22-page, Arial size 10, single-spaced, narrow-margin, triple-checked, essentially complete application "I can't see what you've done since last promotion". It was code for 'I can't see how much money you have made us since last promotion'. It was also said to me, "being bold is good, but don't you think you're being too bold?" — a nod to my 0.5FTE (Full Time Equivalent) they conveniently pretended I was able to stick to in order to complete their absurd workload and expectations, and would not have been able to talk about as much as I did if I had.

What was a no-brainer now had me defending my very existence. I climbed that mountain every day for ten years by working from home. Had I not had flexible working arrangements, I'd be stuffed. But it was a catch-22. Because no one could see me except for the occasional pop-in for a quick chat on the days I lectured, they dared not trust me across the full week. They always had something they could pretend was true-that I had 
a questionable work ethic because of my competing love for my family-to not support me, my dreams, my ambitions, my hopes, my capabilities, my potentials, my worth. In their mind, they had already done me a massive favor by letting me work from home. To them, this warranted making a hugely consequential error of judgment: that because my time competes, so do my passions, so does my worthiness.

It gets uglier. As I stepped away from my stuffed workload while on Long Service Leave during 2020- 'busywork' [2] intentionally designed so academics do not have time to be truly creative or become too aware of just how unjust their situation is-I spent some time reading books that helped me do both. I launched a consultancy and designed my own website, which satisfied a human yearning to stretch my knowledge base and curiosity about what I am capable of achieving. I also repeatedly read what I had come to discover at the time I established the Issue-that only about $25 \%$ of Full Professors in western countries are women, and only about $1.5 \%$ are women of color [3] - even though there are many more of us than that at graduation. If ever there was a fact to remind me the world only sees my body, not my humanity, that was it. As Oluo says, "what many Black women find out when we try to lead (is that) we are the only ones who have any faith in us" [4].

After I received that unsupportive response to my "draft" application, I went back and added even more, making it in the end 42 pages long (not including the supporting documentation of recent and seminal publications but including a lengthy equity statement that was narrative therapy for me but handed over the power of knowledge to them). In total, I spent $110 \mathrm{~h}$ across one full year to write that application. I searched for every silly little detail that might support what I was saying and changed the language to speak like the braggart I loathe, but by the time the updated version was finished a spectacular and ironic fork in the road faced me.

With universities choosing to shed approximately $10 \%$ of their permanent staff to cope with the revenue loss derived from the international student pipeline [5], rather than using the billions they have in reserves [6] which is what the definition of a reserve is, I was faced with the choice as to whether I submit my application for promotion or my notice of intent to take a voluntary redundancy. I chose the latter. Hours and hours of painstaking labor put into the hope I would finally be seen was to no avail. I chose the existential silence of walking away, knowing no one will really care and justice would not be done.

It is this same silence that explains why only four submissions to this Special Issue were received, and almost all in the month just prior to or after its closing date. In the pandemic's 'pink recession', there is a person behind every one of those job losses. She will have rent to pay, a mortgage, bills, and the mouths of babes to feed. As Paul Brodeur says, "statistics are humans with the tears wiped off" (unsourced) [7]. The Call for the Special Issue was known to over 2000 women across 38 countries who visited my website during the year (where I had also mentioned it), yet almost every single one chose silence. Now was not the time to speak about the sexism they had experienced which prevented them from being seen and paid for their valuable contribution to the workplace, assuming they even had a second to spare while home-schooling through the pandemic [8]. Now was the time to lay low and be grateful they had a job. Publicly standing with a woman of color with no structural power or privilege to share or borrow from in an already precarious circumstance was also a professionally risky tarnish-by-association, which is why she speaks mostly standing alone and why more widespread privately shared solidarity is beneath what is visible to the world.

Every time I pushed out another paragraph for my updated promotions application, an outburst would fall out of me. "Can you see me now?", I would scream at my computer. I chose the voluntary redundancy because of a whisper in my ear that would not stop getting louder: "No Pooja, they still cannot see you. They will never see you. You were never meant to be seen. This system was designed to ensure it did not see you. It does not know how to value you because it was never meant for you". 
Choice is a funny thing. I did choose to leave, but I lost everything in doing so. Twenty years of being an academic had no worth. I left my last university after ten years there, at the level I should have been employed at. I jumped through hoops to even get there. I left that university with less money in the bank than when I started. I was a middle-aged woman who had raised and financed four children, and now had the same money I had when I graduated from my PhD 16 years ago. I am the new 'highly educated working poor'. I was never meant to be seen.

One of the reasons powerful people could not see what I had done since last promotion was because, in that time, I had experienced 65 rejections of my manuscripts. On face value, one might think I suck at writing. What I was really being denied was the benefit of the doubt — an inherent message built into the research dissemination system that women of color are equally worth supporting and giving a chance to; that someone like me had something valuable to say, that represents issues people like me think about and are affected by, and could be enhanced with the help of collegial and constructive reviewers who know how to come into another person's story and do not see their way as the only way.

It was because I could write that the attention of editors moved from my grammar (picked on by authors from the global South majority who speak multiple languages but have to publish in one they may not be fluent in to have any real chance of success) to what I was actually saying, and as long as it ruffled feathers it got chopped. (And truth always ruffles feathers). New to the allowable current knowledge base equals controversial, and out of the mouth of a woman of color equals unsafe. No 'any publicity is good publicity' here. The impact factors of journals go down the more they publish women [1]. They're already losing by letting us take up space on their pages. Didn't I know? I was lucky to be here.

Bending its rules with the audacity to think of myself as more than just a 'knowledgedocumenter' and an actual 'knowledge-creator' was not a luxury designed for me. Intellectually ripening into a commentator-whose personal perspective holds weight-steps outside the tiny box I was meant to stay in. My preassigned duty-if I was to stubbornly choose to stay here-was to merely but articulately describe what we all already knew. I was not to use the opportunity of long investment in my research training to decolonize knowledge, or speak as if I know what I'm talking about. Thought leadership is not meant to come in the package I do. Neoliberal academia_prizing stupid things like a journal's impact factor over how thought-provoking, interesting, valuable, unique, different, useful, and truthful a piece of work is-is a risk-averse, reputation-hungry, money-thieving beast.

At first, I did the normal human thing of thinking it was me. Especially trained to stay small as a woman of color, deprogramming out of that cognitive pattern took much time. But at some point, I finally did click over, and realized I was being gaslit and bullied with a scrutiny a man would never know. This is why $75 \%$ of Full Professors are men. Their journey to the top is consciously and unconsciously lubricated. The system knows how to see what he is doing because it was made for him. He represents the objective genderless, raceless, classless truth, and everyone else just has an opinion. Because the job of science is to dismiss opinion, well ... you know the rest. This is why the work of men is perceived as of 'higher scientific quality' and so cited more often [1], and why women develop 'cite clubs' vowing to mostly or only cite each other $[9,10]$.

As I remained gagged and hidden on a long rejection belt-on work that other expert Professors with no competing interest described as "a seminal study", "a must read", "innovative and applicable", "ambitious, valuable, and compelling reading", "hope will be highly cited as landmark research", "its project account a rare gift to the scholarly community", with "attention to detail, comprehensiveness, and transparency that is commendable", and which cost me $\$ 50 \mathrm{~K}$ in unfunded research [11] — I was unable to build track record. Without that, I could not get a grant. Without that, I could not get promoted. For many academics, their higher degree is no longer the ticket to somewhere the marketing told them they might get to. For many, they will depend on their union to protect them from 
increasing pay ratios between themselves and Chancellors at already highly undeserving and non-sensical disparity.

It might be worth management teaching a course for a full semester with the full responsibility of a convenor to remind them what it involves and how much it has changed since when they last did it. Teaching hundreds of students across digital means and doing serious emotional labor to work out how best to meet the needs of each student with barely any resourcing and support is a trench they need to revisit. They are so far removed, in their ivory tower, they cannot see their complicity with the abuse, exploitation, and coercive control of their staff which they quickly shift blame to a neoliberal government to. They cannot see how severely defunct their Teaching Allocation Tools (TATs) are to help kid themselves they are not breaching the Enterprise Bargain Agreement (EBA) about the allocation of work that is reasonable and fits in a $37.5 \mathrm{~h}$ week. Perhaps they can, and still don't care (oh, the toxic lure of money): so much worse, for which there are no words.

That there are no real legal protections and accountability systems in universities for their now well and truly entrenched systemic wage theft is gob-smacking. I don't know how it was allowed to happen (by employing someone who speaks excellent loophole legalese, no doubt), but the EBA contains an empty circular clause that helps them break it: staff cannot work overtime without the written permission of their supervisor, yet this would mean that their supervisor would then need to breach the policy and dedicate one full day of their working week just to signing everyone off: something they would not be allowed or want to do. The effect: you cannot legally work overtime, but if you do to meet workload and criteria for promotion, it's your fault and you will still be told you have not done enough.

Academic staff in Australia donate approximately $\$ 1.4$ billion per year in unpaid labor to their employers [2]. In just three years, between 2007 and 2010, more than 5000 recorded non-disclosure agreements (NDAs) were signed in British universities [12]. Referrals to counselling services among university staff in the UK have increased by between $123 \%$ and $424 \%$ since 2009 , with women making up $70 \%$ of the referrals [13]. I could go on, and these trends are globally transferable. I don't know the data on the exit rate, but I would hazard a guess it's women of color likely to go first. My story is my life and I lived through it, but it was nothing more than a predetermined story from a history so far back it's hard to say what's truly my own.

To claim as much as I can back, I chose to write this Editorial in first person. Speaking in first person is my enactment of 'radical self-care is political warfare' [14], as Audre Lord so poetically and painfully captures. At every turn it could, academia took my voice because it thought it owned me. It loved being my gatekeeper. That's how it kept its power. It needs me to feel and be powerless. It needs me to think that someone else always owns my words and my truth.

If I have a comma out of place, I will now defend its right to be out of place. Too often it has been moved by a copyeditor when I didn't want it touched and had intentionally put it there. Some papers were so tampered with that the titles and sentences of already accepted manuscripts were reworded and entire paragraphs deleted without my knowing. I never looked at them again: I did not recognize them as my own. I do not need or want anyone's permission to speak or exist anymore. Defending my right to a misplaced comma is my resistance to the intellectual oppression I was expected to silently and graciously accept, endure, and survive as a woman and of color.

Dear (neoliberal) academia-you can have your title. I will scrape by on humble earnings, on work that does not make me contort myself to fit a box I was never meant to fit. Your elusive and illusory partially reinforced carrot will no longer whip me. I will not stay to continue to know my place and use my tools to build your house [15]. I will not finally show up on my knees and then be told to lick your shoes. Until there are just as many mediocre women of color at a table of power as there are mediocre white men, or where I can comparatively speaking 'whip up' a promotions application and it be good enough, the word 'meritocracy' has no meaning. 
Professorial management in institutions that stand for truth, ethics, rigor, and integrity, and assumed to be the face of these institutions for having built their own careers on these characteristics, (intentionally?) use the wrong metric to make their women feel like failures as good capitalist subjects and justify making their living by stealing ours. When an academic chooses this career path, they are signing up to a lifetime commitment to seek and speak truth derived from ethical, responsibly self-reflexive, and rigorous means. It is their raison d'etre, what the public pay for and expect, incur repercussions when they don't, and the real metric by which they wish to have their performance judged. I do wonder how they sleep at night. When staff raise their anguish-riddled grievances but are dismissed with the unflappable brevity of power and privilege, they are reminded of what they knew all along: they never stood a chance. If I give them the benefit of the doubt, and they are willing to listen, I have two things to say: never ask a woman why she didn't speak up, never give her work that exceeds legal workload.

I now turn to the wonderful women who made a contribution to this Special Issue. Dr Merryn McKinnon and Dr Christine O'Connell write a compelling piece that exposes the detail and intricacies of sexism in STEM. When they first emailed with their expression of interest to submit a manuscript, I said "I look forward to settling into a sofa and reading the truths we speak through each other". The need to be seen and heard as reflected through our shared stories was a hunger, if not justice, fulfilled. They sweep wide through the landscape of intersectionality to situate the personal pain of being an undervalued, underpaid woman in neoliberal academia. Using rigorous qualitative methods, their pages are filled with the centered voices of women who sometimes were speaking about sexism in their discipline for the first time. Of all the many voices-each one pricking something inside- the one that had me seeing red the most was the one who considered an abortion to protect her career. "Micro" aggressions compound to eventually create stark inequality, but their research shows that women mentors who do not pass their own discrimination on to fellow women through harshness, and white men allies, are identifiable resources in need of nurturing. Such strategies will move the conversation from a woman in need of fixing to a system in need of fixing.

Professor Ausra Maslauskaite also situates deep thinking about the intergenerational upward mobility of women within a broad lens, specifically of radical neoliberalism, but applied to the issue of women's access to education in post-Communist Lithuania rather than their access to promotion within educational systems. Themes of how gender and cultural capital might be connected in these conversations are transferable. Using a recent national dataset, it was found that in the cohort first affected by the transition to market economy the transmission of an intergenerational educational advantage was stronger for women. This sends the message that their desire for tertiary education is strong and in need of ongoing support.

Dr Margaret Hodgins continues the global representation of women's voices and experiences in this Issue by offering a piece from Ireland. From the get-go, she had me shaking with nerves of how this story would unfold. I sat on the edge of my seat, gripped. Seeing the words 'sexist discrimination' and 'litigation' on the first few pages signaled that the pussy-footing, conveniently overestimated goodwill, and unshakable expectation of staff to be likable above all else so that they can then be blamed for enabling their own exploitation had left the building, and painful truth to power was about to be spoken. Learning from her about sinister silence-protecting 'stealth power' was particularly important for me in helping name the problem better. My learning deepened with every page. There is a citable line in every paragraph, that just makes you shake your head with shock that at core her story is your story and most every other woman's story. The experiences of this chronically overlooked and unappreciated Head of School were central to the establishment of the Athena Swan Charter. Having them documented here is a privilege I in no way underestimate.

Finally, Professor Margaret Sims, famed author of "Bullshit Towers: Neoliberalism and managerialism in universities in Australia", also makes a most welcome contribution to the 
Issue. Her article begins with the same theoretical frameworks used within her book, as the starting point for moving to a conversation about hope. Women in academia are likely to find themselves knowing a state of helplessness and worthlessness that does not just last for a few years as if it were a normal and shared hardship and setback in life, but one that has lasted decades, perhaps an entire career. Genuine hopefulness, agency, choice, resources, dialogue, and power are critical for those who stay. Fighting the patriarchal "class war from above" to create a new, more equitable social imagining-where their labor is recognized and rewarded in a timely way, and boosts their enthusiasm for their work-will not be possible without them. Timely, strategic, impactful 'call-outs' are called for, including ownership over narratives of exploitation, solidarity with those also willing to narrate them, and intentional choice to behave in value-led ways.

In closing, I thank these five amazing women for their valuable time and intellect, and heart-breaking experiential injustice that moves their pen. Like so many women in academia, their current titles either do not correctly reflect their professional age, worth, and wisdom (rather than their financial pulling-power-a 'one size fits men' [16] metric), or do but were granted so much later than they should have. Thank you for breaking the silence we 'choose'.

Funding: This research received no external funding.

Institutional Review Board Statement: Not applicable.

Informed Consent Statement: Not applicable.

Data Availability Statement: Not applicable.

Acknowledgments: I will not engage in a game that expects me to be grateful for what I do have, to rationalize, justify, or defend injustice and inequality: if meritocracy had merit, I should have been able to make it on my own-I worked hard, and it was good work. The path to genuine material recognition without detrimental impact on livelihood-not just a few kind words, that don't put food on the table-is not objective, level, or transparent (yet, they cling to these untruths). I have more access to opportunity than women of previous generations, but what's the point if I have to act like a man, and am assumed I can, to keep it? Still, the catharsis of writing this Editorial has brought me closer to the privileges the external world has given me that allow me to write it at all (and for every one of these is the source of strength and beauty for that person repeatedly told by that same external world they are of less value): I am on the lighter end of 'colored', I can seamlessly code switch to an Australian accent, I do not wear a hijab, I grew up middle class, I come from a 'model minority' group, I am not too large, too young, or too old, I bathe in the blissfully ignorant downstream invisible waters of able-bodiedness and cis- and hetero-normativity, I am not torn from war-torn lands, I am not torn from my own land, I am not detained as if a criminal for wanting safety for my children, my children have not been stolen from my people, I am not plagued by mental illness mislabeled a personal failure to cope and told to just get over when it's really systemic oppression, I am free of nightmares from complex PTSD, I live in a country where I can speak freely and have access to free and quality healthcare, fear of deportation does not silence or invisibilize me, I do not clean toilets for a living with my bare hands like the Thai woman I saw in the hotel I stayed at decades ago, I am a second generation adult with the opportunity to enjoy the best of collectivism and individualism and power to reject their worst, I was educated in a university pre-neoliberalism and grew exponentially in that intellectual freedom, all my direct bosses have seen and know my worth, I do not fear my successes being attributed to being 'wooden', the financial generosity of my in-laws ensured we always had a roof over our head, I know the joy and pleasure of genuine friendship, I have a green garden I can weed and mow, I sing loudly when alone in my car, my son heals me, my mother's food heals me, my three stepsons respect me and are thriving in their lives, my white husband is my laughter and superpower, the entire Maharashtrian and Hyderabadi community and other South Asian diaspora in Sydney has my back, my brother is my go-to for everything, and my parents have and will go to the ends of the earth for me. It would be unbalanced and remiss of me to not acknowledge the immunity shots that buoy me. There is one more: I nearly did not write this Editorial. A random act of kindness received from the Managing Editor, Alice Li, in one of our email exchanges unplugged me from the grief and despondency she found me in. 
Conflicts of Interest: I declare no conflict of interest. My experiences are not unique to me or the university I experienced them at. My experiences were coincidental to the university I worked at while simultaneously being a mother. They are shared by most women, not all of them mothers, in all neo-liberalized universities across the world.

\section{References}

1. Holman, L.; Stuart-Fox, D.; Hauser, C.E. The gender gap in science: How long until women are equally represented? PLoS Biol. 2018, 16, e2004956. [CrossRef]

2. Sims, M. Bullshit Towers: Neoliberalism and Managerialism in Universities in Australia; Peter Lang: Oxford, UK, 2020.

3. Crimmins, G. A Structural Account Of Inequality In The International Academy: Why Resistance To Sexism Remains Urgent And Necessary. In Strategies For Resisting Sexism in the Academy: Higher Education, Gender, and Intersectionality; Palgrave Macmillan: Melbourne, Australia, 2019; pp. 3-16.

4. Oluo, I. Mediocre: The Dangerous Legacy of White Male America; Hodder \& Stoughton General Division: London, UK, $2020 ;$ p. 197.

5. Doughney, J. Without International Students, Australia's Universities Will Downsize-And Some Might Collapse Altogether. The Conversation, 8 April 2020. Available online: https://theconversation.com/without-international-students-australias-universitieswill-downsize-and-some-might-collapse-altogether-132869 (accessed on 6 June 2020).

6. Marshman, I.; Larkins, F. Modelling Individual Australian Universities Resilience in Managing Overseas Student Revenue Losses from the Covid-19 Pandemic; Centre for the Study of Higher Education, The University of Melbourne: Parkville, Australia, 2020; Available online: https:/ / melbourne-cshe.unimelb.edu.au/lh-martin-institute/insights/modelling-individual-australian-universitiesresilience-in-managing-overseas-student-revenue-losses-from-the-covid-19-pandemic (accessed on 6 June 2020).

7. They Said So ${ }^{\circledR}$. Available online: https://theysaidso.com/quote/paul-brodeur-statistics-are-human-beings-with-the-tearswiped-off (accessed on 16 January 2021).

8. Ferrara, E.M. Baby Matters: Gender Politics Beyond Covid-19 and the "Aunts" of Academia. Academic Matters, 29 June 2020. Available online: https:/ / academicmatters.ca/baby-matters-gender-politics-beyond-covid-19-and-the-aunts-of-academia/ (accessed on 16 January 2021).

9. \#FEAS Feminist Educators Against Sexism. Available online: https://feministeducatorsagainstsexism.com/cite-club/ (accessed on 16 January 2021).

10. Ahmed, S. Living a Feminist Life; Duke University Press: London, UK, 2017.

11. Edwards, R. Why Do Academics Do Unfunded Research? Resistance, Compliance and Identity in the UK Neo-Liberal University. Stud. High. Educ. 2020, 1-11. [CrossRef]

12. Connell, R. The Good University; Monash University Publishing: Melbourne, Australia, 2019.

13. Morrish, L. Pressure Vessels: The Epidemic of Poor Mental Health among Higher Education Staff. Available online: https://www. hepi.ac.uk/2019/05/23/pressure-vessels-the-epidemic-of-poor-mental-health-among-higher-education-staff/ (accessed on 13 March 2021).

14. Lorde, A. A Burst of Light and Other Essays; Firebrand Books: New York, NY, USA, 1988.

15. Lorde, A. The Master's Tools Will Never Dismantle the Master's House. In Sister Outsider: Essays and Speeches; Crossing Press: Berkeley, CA, USA, 1984; pp. 110-114.

16. Perez, C.C. Invisible Women: Exposing Data Bias in a World Designed For Men; Chatto \& Windus: London, UK, 2019. 